Article

\title{
The Theoretical Foundations of Contextual Interpretation of the Qur'an in Islamic Theological Schools and Philosophical Sufism
}

\section{Halim Calis}

Citation: Calis, Halim. 2022. The Theoretical Foundations of Contextual Interpretation of the Qur'an in Islamic Theological Schools and Philosophical Sufism. Religions 13: 188. https://doi.org/ 10.3390/rel13020188

Academic Editors: Ismail Albayrak and Hakan Coruh

Received: 2 January 2022

Accepted: 14 February 2022

Published: 21 February 2022

Publisher's Note: MDPI stays neutral with regard to jurisdictional claims in published maps and institutional affiliations.

Copyright: (C) 2022 by the author. Licensee MDPI, Basel, Switzerland. This article is an open access article distributed under the terms and conditions of the Creative Commons Attribution (CC BY) license (https:// creativecommons.org/licenses/by/ $4.0 /)$.
Respect Graduate School, Bethlehem, PA 18017, USA; hcalis@respectgs.us

\begin{abstract}
Contextual interpretation of the Qur'an has grown in popularity with the rise of Islamic modernism, mostly because of the need to reform Islamic thought and institutions. Although Qur'anic contextualism is a modern concept, this study argues that its theoretical origins can be traced back to classical Islamic scholarship. Most of the Islamic theological schools, as well as the Akbarī School (the school of Ibn al-'Arabī), a prominent representative of philosophical Sufism, acknowledged the contextuality of the Qur'an by distinguishing between transcendent divine speech and its limited manifestation in human language. Furthermore, Shams al-Dīn al-Fanārī of the Akbarī School developed a hermeneutical theory in which he questioned the authority and the nature of Qur'anic exegesis and emphasized the idea that the Qur'anic text can have multiple meanings, due to the multiplicity of perceptions in different human contexts. I propose that, of the thinking in pre-modern Islamic scholarship, Akbarian scriptural hermeneutics best accommodates the modern practice of reading the Qur'an contextually.
\end{abstract}

Keywords: Qur'anic exegesis; Qur'anic contextualism; Islamic reformism; Islamic modernism; Islamic theology; philosophical Sufism

\section{Introduction}

'Alī ibn Aḥmad al-Wāhidī (d. 1075), a renowned medieval Qur'an commentator, is reported to have made the following statement about Muhammad ibn al-Husayn al-Sulamī (d. 1021), who compiled a collection of Sufi comments on the Qur'an: " "Abū 'Abd alRahmān al-Sulamī compiled the Haqā'iq al-tafsīr. If he believed (i'taqada) that this was a commentary (tafsīr), he would be an infidel (kafara)" (Ibn al-Salāh 1980, p. 35; Al-Zarkashī 1957-1958, vol. 2, p. 171). This criticism may sound odd to modern readers, who might not understand why personal comments on a text should make an author an infidel. I think al-Wāhidī's opinion can be considered partly based on the belief that the function of exegesis is to reveal divine intention in the Scripture; therefore, $t a f s \bar{s} r$ is undertaken to understand God's mind in the sacred text. Another premise should be also taken into consideration: the only legitimate source for the comments is knowledge transmitted from early generations, especially from the Prophet and the companions; no comment can be based on anything other than tradition. Thus, we can read al-Wāhidī' s statement as "if al-Sulamī believed that these comments, not based on tradition, were the real meaning of God's words and meant by God, he would be an infidel". ${ }^{2}$

Al-Wāhidī's opinion is, as a matter of fact, the standpoint that one of the major tafsìr schools, exegesis based on narration (tafsīr bi al-riwāya), has adopted. Reducing tafsīr to transmissions from earlier generations has never been accepted as the sole way to understand the Qur'an since the early centuries of Islam. Objections to traditionalism in exegesis became stronger during the time of Islamic reformism and Islamic modernism, when the perceptions of many Muslims underwent changes, and new quests emerged in the field of scriptural hermeneutics. Among the new ideas in this era of non-traditional, 
modernist hermeneutical practices, "contextual reading" of the Qur'anic text stands out as one of the central notions. ${ }^{3}$ Qur'anic contextualism can be defined as a principle-oriented approach to the scriptural text, unlike the literalist/textualist approach, which accepts only the literal meaning of the text as it was understood at the time of its emergence and takes this original meaning as binding for all times and places. The contextualist method takes into account the socio-historical context in which the text appeared, with the aim of determining the principles that were intended, not only what is understood in the historical context. In this sense, the meaning of the text is not considered binding for all times and places.

The most crucial task in establishing a contextual approach is to determine the Prophet's role in the revelatory process, since if the Prophet is solely acknowledged as the passive receiver of an immutable message, the contextuality of the message would be irrelevant. As a result, contextualism must highlight the Prophet's role in revelation to the point where the Prophet becomes an active agent that gives the divine message its final shape. Contemporary contextualists frequently refer to some concepts in Qur'anic Studies that have been discussed since the classical period, such as asbāb al-nuzūl (occasions of revelation), naskh (abrogation), $t a^{\prime} w \bar{\imath}$ (interpretation by reason), and sab'at ahruf (seven readings) $;^{4}$ however, they do not appear to be sufficiently interested in the classical theological discussions to seek theoretical support there for the Prophet's active role in the revelatory process. Some leading contexualist scholars, such as Fazlur Rahman (d. 1988), even criticize Orthodox Muslim theology in this respect. He states,

Orthodoxy (indeed, all medieval thought) lacked the necessary intellectual tools to combine in its formulation of the dogma the otherness and verbal character of the revelation on the one hand, and its intimate connection with the work and religious personality of the Prophet on the other, i.e., it lacked the intellectual capacity to say both that the Qur'an is entirely the Word of God and, in an ordinary sense, also entirely the word of Muhammad. (Rahman 1979, p. 31)

Abdullah Saeed, who seems to agree with Fazlur Rahman on the difficulty of building contextual approach on the Orthodox theology, directs his gaze in another direction to justify contextualism. Pointing out that concepts of revelation and interpretation are not necessarily connected, Saeed believes that Qur'anic contextualism can be based on the fact that "the language of the Qur'an, Arabic, is a human language, deeply embedded in human life" (Saeed 2006, p. 28). He further emphasizes the status of the Qur'an as God's speech in human language, which means that revelation couched in human language is capable of being analyzed (Ibid., pp. 27-28).

In this study, I argue that the theoretical foundations of contextualism can be found in Orthodox Muslim theology and philosophical Sufism. Naturally, we do not expect to find, in the historical Islamic scholarship of centuries ago, modern rhetoric and arguments about contextualism, including a heavy emphasis on the Prophet's role in revelation; nevertheless, the scholars of the time did construct theories that may be seen as precursors of Islamic contextualism. In the following pages, I will first provide a brief outline of modern thought regarding the non-traditional approaches to the Qur'an developed by selected representatives of Islamic reformist and modernist movements, to show how the development of contextual interpretation of the Qur'an arose from the reactions of Muslim intellectuals to the decline of the Muslim world in the 18th and 19th centuries. Then, I will focus on early Islamic theological debates over divine speech (kalām) and its verbal form as sacred scripture in human language. In the subsequent section, I will explore the explanations put forth by Akbarī Sufis such as Ibn al-'Arabī (d. 1240), Șadr al-Dīn al-Qūnawī (d. 1271), and Shams al-Dīn al-Fanārī (d. 1431) regarding how divine speech manifests in human language. We will clearly see in these two sections that the Akbari Sufis and the majority of Muslim theologians accepted sacred scripture as a contextualization of the divine speech. In the penultimate section, I will examine various viewpoints on the authority of Tafsīr (the Islamic discipline of Qur'anic exegesis) to identify divine intention in the Qur'an, i.e., the true meaning of the text intended by God. The major purpose of 
accepting the contextuality of the text is to be able to propose readings as alternatives to traditional ones, which necessitates questioning the nature and boundaries of exegesis of the Qur'an, for, if a certain meaning is regarded as the expression of divine intention-i.e., as the only genuine meaning of the text-there would be no room for the idea of the contextuality of the text. In this section also, I place special emphasis on the ideas presented by the most outstanding representatives of philosophical Sufism, the Sufi writers of the Akbarī School. Overall, I believe that the Akbarī standpoint on Scriptural hermeneutics best accommodates the modern concept of contextual reading of the Qur'an.

\section{The Rise of Islamic Modernism and Contextualist Method in Exegesis of the Qur'an}

The primary motivation behind non-traditional readings of the Qur'an in the modern period is the need to reform Islamic institutions, especially the Islamic legal system. The idea of the "changeability of Shari'a rules with changing times", which has been discussed since the early days of Islamic reformism, inevitably brought the idea of alternative interpretations of the Qur'an to the table. ${ }^{5}$ For example, Rifā'a Rāfi' al-Taḥtāwī (d. 1873), one of the most important political thinkers of modern Egypt, who had a chance to study French thought and closely observe Europe during his education in Paris, expresses the idea that Shari'a law should be considered changeable and adaptable to changing circumstances. This requires a new and more flexible interpretation of Shari'a in the light of modern needs and a reexamination of the authoritative texts for this purpose. al-Tahtāwi does not object to new interpretations that are in line with modern developments, since he believes that Islamic principles are not that dissimilar from the modern natural sciences that the modern world is developing on. ${ }^{6}$ Khayr al-Dīn Pasha of Tunisia (d. 1889), another early representative of Islamic reformism, also finds no problem with taking ideas and institutions from Europe but sees them as being in keeping with the spirit of Shari'a, rather than contradicting it. He defends the notion that laws and policies change as circumstances and societal needs change, and, therefore, Shari'a does not cover all aspects of human and governmental activity. He further emphasizes the Islamic idea of mașlaha (public interest) as a crucial element to be upheld in the legislative process. ${ }^{7}$

Similar perspectives were articulated by succeeding reformist and modernist thinkers. For example, Jamāl al-Dīn al-Afghānī (d. 1897), the great champion of pan-Islamism in the 19th century, equates the essence of Islam with modern rationalism, accepting that the type of knowledge received by the prophets through revelation can be acquired by philosophers through the use of reason. Human reason should be the major tool in interpreting the Qur'an. If the Qur'an and reason appear to contradict each other, the Qur'an should be interpreted symbolically. According to al-Afghānī, the Qur'an contains many hidden secrets that have remained unknown until now, a time when human reason has progressed to the point where it can uncover these truths (Hourani 1983, pp. 103-29) ${ }^{8}$. According to Mehmed Seyyid Bey (d. 1925), a scholar and a statesman from Ottoman Turkey who played a major role in the abolition of the caliphate in 1924, one of the bases of Shari'a law is human reason, which has the power to discern what is good and bad in this world. This concept is crucial to Seyyid Bey because it permits him to assign greater authority to reason in interpreting sacred texts and formulating laws. In the process of interpreting the sacred book, he places a great emphasis on the concept of maqāșid al-Shari'a (the purposes of Shari'a) (Seyyid n.d., vol. 2, pp. 255-324) ${ }^{9}$. He prioritizes mașlaha (public interest) when it conflicts with Qur'anic and Prophetic statements, claiming that this preference does not mean he is disregarding the sacred texts, but rather, embracing their spirit and objectives (Ibid., vol. 2, p. 311).

Initial reformist quests gave birth to later secularist trends in Muslim scholars, as secularist ideas also arose independently among westernized intellectuals. The emphasis was on the separation between state and religion more than on the changeability and adaptability of religious laws. For example, 'Alī 'Abd al-Rāziq (d. 1966), an Egyptian secularist, bases his views regarding the lack of need for a caliphate on the fact that both the Qur'an and hadith are silent on the subject. He questions if Islam suggests any 
kind of government and whether political authority is a function of prophethood. He comes to conclusion that Prophet Muhammad's role was purely spiritual. He created a community not a state (Hourani 1983, pp. 182-89). Another Egyptian secularist, Ṭāhā Husayn (d. 1973), who has enormous admiration for Europe and European civilization, maintains that Egypt must be a part of Western civilization. As the modern world is built on the separation of religion and civilization, Egypt must do the same, and can do so more readily than Christianity because Islam, which has no clergy in the Christian sense, makes this separation simpler. Besides, the real Islam is a religion of science, knowledge, and progress. Husayn believes that when religion educates mankind, it conveys its truths through symbols. These symbols should be retold anew as humans' understanding evolves over time (Ibid., pp. 324-40).

Many other names could be mentioned here of those who questioned the relevance of religious laws to today's world, but I believe it is enough to mention the ideas of these reformist and secularist representatives to demonstrate that their minds were preoccupied with the problem of conflict and reconciliation between the past and the present. Modern Qur'anic contextualism arose under such circumstances, and its proponents saw it as the only way to justify the idea of changeability of the laws with changing times.

Contemporary modernist scholars engage in more sophisticated theological debates on the nature of revelation when they attempt to rationalize contextualism. One of the most critical components of their understandings is the emphasis they place on the role of the human prophet in the revelatory process. According to Fazlur Rahman (d. 1988), for example, the Qur'an is the Word of God, but since it emerged in a human environment when received by the Prophet, it can also be accepted as the word of the Prophet. He states, "the Qur'an is thus pure divine Word, but, of course, it is equally intimately related to the inmost personality of the Prophet Muhammad whose relationship to it cannot be mechanically conceived like that of a record. The divine Word flowed through the Prophet's heart" (Rahman 1979, p. 33). Rahman criticizes the Islamic orthodoxy that emphasized the externality of the revelation "in order to safeguard its 'otherness,' objectivity and verbal character" (Ibid., p. 31) and, thus, failed to recognize the Prophet's revelatory experience as personal experience in his "deeper strata of consciousness" (pp. 13-14). According to him, the idea of the "otherness" of the revelation is maintained in the Qur'an; however, its "externality" to the Prophet is equally rejected (Ibid., p. 31).

Since the divine speech acquires a certain shape in and according to the Prophet, who lived in a certain socio-historical context, an understanding of that context is critical for Rahman to comprehend the message of the Qur'an thoroughly. Hence, he introduces his theory of what he calls "double movement" in the interpretation process (Rahman 1984, pp. 5-7). He states,

The process of interpretation proposed here consists of a double movement, from the present situation to Qur'anic times, then back to the present. The Qur'an is the divine response, through the Prophet's mind, to the moral-social situation of the Prophet's Arabia, particularly to the problems of the commercial Meccan society of his day. (Ibid., p. 5)

In the first step of this "double movement", the principles that the Qur'an wishes to attain are explored through an examination of its socio-historical background. On the basis of these Qur'anic principles, fresh interpretations suitable with the modern period are provided in the second step.

Whereas Fazlur Rahman focuses on the theological aspect of contextualism, Nasr Hamid Abu Zayd (d. 2010), an Egyptian scholar of Qur'anic Studies, bases his contextual reading on historical and literary criticisms. ${ }^{10}$ Abu Zayd embraces contextualization as his methodology to distinguish between historical and universal messages of the Qur'an and Islam. Concluding that the Qur'an is a cultural production, he tries to understand this text in its cultural and socio-historical contexts. He also treats the Qur'an as a linguistic text amenable to textual analysis, emphasizing that the Qur'an became a human text when it was transferred from the divine realm and revealed to the Prophet. Therefore, 
he employs some other methods in addition to historical criticism, such as semantics and semiotics, to explore the human dimension in the text in addition to the historical and cultural dimensions. Abu Zayd introduces some concepts, such as the "direction of revelation" (ittijäh al-nașs ) and the "tacit or not mentioned (message of the text)" (maskūt "anh) to complete his hermeneutical methodology, which claims to establish the relevance of a historical text to today's context, or any other. When applied to the controversial issue of polygamy, for example, Abu Zayd's hermeneutical method leads to the conclusion that the direction of revelation in the Qur'an points to the tacit message of the text, which is the prohibition of polygamy (Abu Zayd 1999).

\section{Debates on Divine Speech in Classical Islam}

Since the first century of Islam, theological speculations made by various Islamic schools and sects have debated the nature of divine speech, that is, whether or not God's speech is an eternal divine attribute, and, if one considers it to be as such, how it manifests in the limited transient world. The problem of heavenly and earthly forms of the Qur'an, related to the problem of divine speech, was also discussed. ${ }^{11}$ It is necessary to be aware of these discussions on divine speech and of the concept of revelation during the formation of Islamic theology, in order to determine whether the modern practice of contextual reading has a basis in Orthodox theology.

Among the theological Islamic sects, early disputes on the divine attribute of speech (kalām) centered on the question of whether or not the Qur'an was created. The Mu'tazilites denied the existence of an eternal attribute of speech subsisting in God and believed that God speaks by creating speech outside Himself. ${ }^{12}$ Therefore, the Mu'tazilites' assertions regarding the createdness of the Qur'an were based on their primary doctrine of negation of the "eternal divine attributes of the Essence." (Gimaret n.d.). They insisted on denying such eternal attributes in order to rule out the conclusion that there are multiple eternal entities besides the essence of God, which would damage the most important Islamic teaching -the unity of God (tawhīd). Mu'tazilite theologians tried to explain God's qualities and acts without approving the existence of any distinct attribute in Him; they said, "God is knowing, powerful, living through Himself (bi-nafsih $\bar{\imath})$, and not through a knowledge, a power and a life."(Ibid.) This principle resulted in a denial of divine speech as an eternal attribute and in an acceptance of the view that the Qur'an was created. ${ }^{13}$ According to alQāẹī 'Abd al-Jabbār (d. 1025), the great Mu'tazilite theologian,, ${ }^{14}$ speech is one of God's acts, which He generates not in, but outside, Himself. Since it is generated and not subsisting with God, it is not eternal. Spoken words or written text are "not speech, but only a sign of speech once spoken" (Peters 1976, p. 417). Thus, God communicates through the speech He creates in an earthly substrate, such as occurred when God spoke to Moses from the burning bush (Ess 1996, p. 181).

Early traditionalist 'ulama' and traditionists (muhaddithūn) were opposed to these ideas of the Mu'tazila. Ahmad b. Hanbal (d. 855), who rigorously refused the Mu'tazilite theses and wrote refutations against them, was the champion of the traditionalist opposition, ${ }^{15}$ and, although the traditionalist view evolved over time, ${ }^{16}$ Ahmad $b$. Hanbal's followers became certain that the Prophet received "verbal inspiration"; namely, the exact words of God came down on him (Ibid., p. 183) ${ }^{17}$. They went even further, claiming that the pronunciation (laf z) of the Qur'an is uncreated (Ibid., p. 184). Thus, the Hanbalīs saw no problem maintaining that God's eternal speech is composite in nature, containing words and sound (Wolfson 1976, pp. 248-54). Later, the Hanbalī Ibn Taymiyya (d. 1328) argued that divine speech was directed by the divine will, so that God spoke whenever He wanted to speak and in whatever language He wanted to use. According to him, the Arabic expression of the Qur'an consists of the exact words of God when recited, but the voice belongs to the reciter and is created. It is heresy to deny that God speaks using words and sound. Ibn Taymiyya emphasized that affirming the uncreatedness of the Qur'an does not mean accepting its eternity. In other words, since God spoke the Qur'an, it is not created; however, it is not eternal either, as it was spoken in time (Madelung 1985). In regards to the 
last detail, Ibn Taymiyya seems to have tried to solve the problem of accepting the eternity of composite things such as words or sounds, which was a target of widespread criticism raised against the Hanbalīs. ${ }^{18}$

Sunni Ash'arī and Māturīdī theologians generally positioned themselves between the Mu'tazila and the Hanbalīs by affirming two forms of God's speech: one eternal and the other the created expression of eternal speech. In this way, their position ran counter to that of the Mu'tazila, who disapproved of the existence of any eternal entity besides God's essence. ${ }^{19}$ They also distinguished themselves from the Hanbali standpoint by accepting the expression of the Qur'an as created. ${ }^{20}$

A Qur'anic concept known as al-Lawh al-mahfüz (the Preserved Tablet) plays a significant role in the Muslim understanding of divine revelation. ${ }^{21}$ The Preserved Tablet is believed to contain the pre-existing heavenly copy of the Qur'an and a record of all the divine predestinations. Some hadith reports describe the Tablet as created (Al-Tabarāni 1994, vol. 10, p. 260). There are differing opinions on whether the pre-existent heavenly copy of the Qur'an in the Tablet is created or uncreated. Generally, the Hanbalīs and their followers among the Sunni theologians believed in its uncreatedness. However, the belief that God created His speech itself on the Tablet seems to have been an idea prevalent among the Mu'tazilī theologians (Al-Ash'arī 1963, pp. 597-600; Wolfson 1976, pp. 274-78). Later prominent Mu'tazilite scholars, such as al-Qāẹ̄ 'Abd al-Jabbār22 and Mạ̣mūd b. 'Umar al-Zamakhshari (d. 1144), ${ }^{23}$ adopted the idea, and later Sunni theologians agreed with them. For example, Abū al-Yusr al-Bazdawī (d. 1100), a renowned Māturīdī theologian, concluded that the text of the Qur'an is an expression of the eternal divine speech "created" by God on the Tablet, or in the Angel (Al-Bazdawī 2003, p. 68). Fakhr al-Dīn al-Rāzī (d. 1209), the celebrated theologian of the Ash'ariyya, also accepted the idea that God communicates his will by creating "sound" in a locus outside Himself or by writing on the Tablet. ${ }^{24}$ Thus, the Sunni theologians from the Ash'ariyya and Māturīdiyya came closer to the Mu'tazilite belief by accepting the idea that God creates something to express His speech outside of Himself, although they departed from it by affirming the existence of an eternal divine attribute of speech.

In addition to the nature of divine speech, Muslim theologians have also discussed how this divine speech came down to the Prophet as Qur'anic revelation. The Qur'an uses the terms inzāl and tanzill in many verses to denote the descension of revelation. ${ }^{25}$ Scholars have presented different opinions on how inzāl and tanzīl took place. Badr al-Dīn al-Zarkashī (d. 1392) summarized the ideas in his famous al-Burhān fì 'ulūm al-Qur'ān, according to which the majority of Sunni scholars believed that the Qur'an was first sent down whole from the Preserved Tablet to the worldly heaven $\left(\operatorname{sam} \bar{a}^{\prime}\right.$ al-dunyā) in the Laylat al-Qadr (the Night of Power), which is mentioned in verse Q. 97:1, and then its smaller portions were revealed to the Prophet during the twenty-odd years of his prophethood, as required by the occasion (Al-Zarkashī 1957-1958, vol. 1, pp. 228-29). What is clear from the Qur'anic exposition is that the Angel functioned as an intermediary who conveyed the divine revelation, and the whole Muslim umma accepted the agency of the Angel in the process. According to the Mu'tazila, the word that the Angel conveyed was "created in him during the act of revelation" (Ess 1996, p. 181). However, Sunni scholars held different opinions, which al-Zarkashī and al-Suyūtị (d. 1505) summarized as follows (Al-Zarkashī 1957-1958, vol. 1, pp. 229-30; Al-Suyūtị 1974, vol. 1, pp. 157-58): (1) the Angel Gabriel received both the $m a^{\prime} n \bar{a}$ (pre-existent form of divine speech) and what it corresponded to as the actual words of the Qur'an from the Tablet and delivered them to the Prophet; (2) the Angel received only the $m a^{\prime} n \bar{a}$, and knowing its correspondences in the Arabic language, verbalized this meaning in Arabic and conveyed it to the Prophet; and (3) the Angel delivered only the $m a^{\prime} n \bar{a}$, and the Prophet verbalized it in Arabic. The first opinion, that what came into existence in the Tablet is identical to what the Prophet recited as the Qur'an, corresponds to the Hanbali view that the Angel passed down God's exact words. In this case, the reciter pronounces exactly what God pronounced in eternity. Other opinions 
were held by the Ash'arī and Māturīdī theologians. ${ }^{26}$ Najm al-Dīn al-Nasafī (d. 1142) from the Māturīdiyya, and his commentator, Mas'ūd b. 'Umar Sa'd al-Dīn al-Taftāzānī (d. 1390) from the Ash'ariyya, agreed with the third view (Wolfson 1976), that the expressions of the Qur'an were created through their recital. ${ }^{27}$

This variety of theological discussions came from attempts to understand the ancient dilemma of how an eternal and transcendental phenomenon-that is, divine speechmanifested in an uneternal and limited context. Mu'tazilites and their affirmers tried to solve the problem by denying the eternality of divine speech and simply accepting God as speaking to a created world by creating speech in it. The Hanbalis and their proponents saw no problem with accepting the words of the Qur'an as spoken by God in eternity as they are-with letters, words, and so forth. In an attempt to avoid falling into these two "extremes," Ash'arī and Māturīdī theologians made a distinction between eternal divine speech and its created form, holding that divine speech somehow was transformed to human language. When these points of view are considered in light of the object of this study, the Mu'tazila and the later Ash'ariyya and Māturīdiyya, who regarded the Qur'an as a created expression of divine speech, can be regarded as taking a contextual approach, for they understood divine speech to be substantiated into words in a context, whether it is the Prophet, the Angel, or the created al-Lawh al-mahfüz. The "classical" forms of contextualism, of course, do not address the changeability or universal bindingness of the ethico-legal teachings of the Qur'an; nevertheles, these theological schools presented ideas compatible with modern contextual interpretations of the Qur'an. As we will see in the following section, the perspectives offered by the Akbari Sufis on this issue appear to fit the contextual approach far better.

\section{Divine Speech and Revelation in the Akbarī School}

Hermeneutical theories presented by the Akbarī school should be analyzed in relation with its ontological theories because it discusses both subjects through the same concepts and terminology. Akbarīs describe both the ontology of divine speech and ontology of existence as having hierarchical levels, extending down from the transcendental divine level to the physical level of creation. Detailed analysis of the ontological theories of the Akbariyya is beyond the scope of this study; nonetheless, to simplify, we may state that beginning from God, upper ontological levels transform into lower levels until they reach physical forms. In a sense, therefore, all these levels are manifestations of the same reality, namely, the divine essence. Another noteworthy point is that the divine essence transcends all qualifications and definitions, but as it continues to manifest at the lower ontological levels, these manifestations become bound by more and more restrictions.

In his writings, Ibn al-'Arabī discusses extensively the ontological levels of existence (marātib al-wujūd), but he does not offer a systematic theory. Șadr al-Dīn al-Qūnawī, Ibn al'Arabī's foremost student and interpreter, is known as the first Akbarī thinker to systematize the ontological levels (Chittick 1982, p. 109). Al-Qūnawī names five ontological levels as "five divine presences" (al-hadarāt al-ilahiyyāt al-khams): divine, spiritual, imaginal, sensory, and all-comprehensive human levels (Ibid., p. 115). Consequently, the subject of the "ontological levels," has become one of the most famous teachings of the Akbari school.

Al-Qūnawi theorizes that similar ontological levels pertain to divine speech, and he provides a lengthy discussion on it in his $I^{\prime} j \bar{a} z$ al-bayān, a partial Qur'anic commentary on the al-Fätiha chapter. There, he explains how eternal and transcendent divine speech, as a divine attribute, manifests as the Qur'an in the last stage after passing through ontological levels. He writes,

As one of the primary comprehensive divine attributes, which encapsulate all the levels of clarity (marātib al-īdāh wa-l-if șāh), divine speech emanates (șadara) from the presence of the Real (Haqq) and reaches us as colored (munsabighan) by the effect $(h u k m)$ of the five essential presences (al-hadarāt al-khams al-aṣliyya) [i.e., it traverses the five ontological levels]. (Al-Qūnawī 1969, pp. 377-78) 
When explaining these levels, al-Qūnawī cites a well-known hadith that reads, "the Qur'an was sent down in seven readings. Each letter of the Qur'an has an exterior (zahr) and an interior (baț). Each letter has a limit (hadd) and each limit has an observation point (matla'/muttala')." ${ }^{\prime 28}$ Al-Qūnawī takes these four notions mentioned in the hadith as the names of the ontological levels of both divine speech and existence. Accordingly, zahr represents the physical manifestation of divine speech that we call the Qur'an. This also corresponds to sensible physical forms (al-șuwar al-mahsūsa) in existence. Batn indicates the deeper form of divine speech and the spiritual level of existence where heavenly spirits (al-arwāh al-qudsiyya) reside. Hadd refers to the imaginal level of existence, which is the intervening realm ('âlam al-mithāl) in Akbarī ontology, the realm that constitutes a zone between each level and the next. Matla'/muttala' is the name of the level of the divine names, which is the origin and the source of the other three levels, as the divine names are the essence of everything that exists (Al-Qūnawī 1969, p. 378). Al-Qūnawī completes the number of the levels by adding a fifth: $m \bar{a} b a^{\prime} d a$ al-muttala' (that which is beyond transcendence) (Ibid., p. 498). This refers to the first ontological level, which is the primal manifestation of the divine essence anterior to the divine names and attributes (Al-Fanārī [1325] 1907, p. 10).

What is the meaning of all this? This is the Akbarī way of solving the problem of how divine speech transforms into human language, similar to the Akbarī explanation of how the "One" manifests as the "Many" in existence, which is the main concern of Akbarī ontology. Al-Qūnawī believes that the divine attribute of speech (kalām) and the divine name of the Speaker (Mutakallim) manifest in lower forms and finally emerge as the Qur'an, just as all existence unfolds from God's names and attributes. As a result, the words of the Qur'an we recite are just the manifestation of divine speech, i.e., its contextualization, at the level of the perceptible world (Al-Qūnawī 1969, pp. 104, 378).

Shams al-Din al-Fanārī, the first Ottoman shaykh al-Islam and the prominent commentator on al-Qūnawī, contributes to the subject by explaining how the Qur'an, which is uneternal because it is composite in nature, consisting of letters and sounds and being subject to change, can be considered compatible with God, to whom neither composite nature nor change can be assigned. He emphasizes different modes of divine speech (Al-Fanārī [1325] 1907, p. 45):

This [revelation] is like the meanings taking the appearance of the imaginal images (șuwar khayāliyya) that contain parts (ajz $\left.\bar{a}^{\prime}\right)$ freed from chronological order (min ghayr taqaddum wa-ta'akhkhur). ${ }^{29}$ Since the imaginal (khayālī) speech is not like the perceptible (hissī) one, it would also not be like the mental ('aqlī) or the spiritual (ma'nawi) speeches for sure.

All the stages of speech mentioned in this passage-perceptible (hiss $\bar{\imath})$, mental ('aqli $)$, imaginal $(k h a y \bar{a} l \bar{\imath})$, and spiritual $\left(m a^{\prime} n a w \bar{\imath}\right)$ - are in fact the ontological levels of existence theorized by the Akbarī School. Al-Fanārī means to say that divine speech was transformed into the Qur'an in human language after passing through various stages, just as the divine names manifest as creation in the last stage of transformation.

Thus, the school of Akbariyya agrees with the Ash'arīs and Māturīdīs in distinguishing among different forms of divine speech. However, regarding the physical form of speech in human language, which is the recited Qur'an, Akbarīs go further by strongly emphasizing the Prophet's role in the revelatory process, or in the manifestation of the divine name of Mutakallim, as they express it in their terminology. Al-Qūnawī explains that divine speech, like every divine attribute, has two aspects: on one hand, it is possessed of absolute singularity (ahadiyya) in respect to its relationship with the divine essence; on the other hand, it accommodates plurality because of its connection with existence. As a result, the compositeness in the physical form of divine speech is due to the multitude of connections it has with creation, just like an eye with a plurality of sight. The eye is one, but its connections with many objects cause a plurality of sight (Al-Fanārī [1325] 1907, p. 45). This means that the composite state of the divine revelation is caused by the receivers, i.e., the human prophets. The distinctive characteristics of divine revelation, such as its 
language and content, are due to the "connection" between God and human prophets. In other words, God's speech is transformed into human language in human prophets, and scriptures, such as those in Syriac, Hebrew, or Arabic, differ from each other, due to the human factor (Ibid.). In short, all prophets are connected to the same reality when they receive revelation, namely, the divine attribute of speaking; however, the same divine attribute manifests differently in each of them according to their differences, as the final "verbal" form of speech takes on a certain shape, depending on the collocutor.

\section{The Authority of Tafsīr to Deliberate God's Intention in the Text}

The varied approaches to the nature of the Islamic discipline of Qur'anic exegesis (Tafsir ) and to its authority to identify the divine intention are an important component of the discussion about contextualism. Contextualists make comments that are manifestly distinct from what has been long held in the tradition. Acceptance of the assertion that interpretation of the Qur'an based on tradition yields the sole meaning intended by God will inevitably leave no room for contextual reading. Objections to traditionalism in Qur'anic exegesis, and alternative methodologies, are not a recent trend. There have been commentators who based their exegesis on sources other than narrations since the early years of Islam. As a matter of fact, the two exegetical traditions of tafsīr bi al-dirāya (exegesis based on intellect) and tafsìr bi al-ishāra (exegesis based on mystical knowledge) are the outcome of an attempt to explain the Qur'an based on frameworks other than tradition. Although the major focus of these non-traditional Qur'anic interpretations was not contextualist in the modern sense, these interpretations can, nevertheless, be regarded as part of the theoretical foundations of contextualism.

The authority of Tafsir has been debated from two angles: (1) whether it can be regarded as an Islamic 'ilm (systematic science), and (2) whether it has the authority to discover divine intention in the text. Two issues have dominated debates over whether Tafsì r should be considered 'ilm in the sense of a systematic Islamic discipline. First, scholars questioned whether Tafsir had principles that would allow it to be classified as a systematic science. Al-Fanārī emphasized that Tafsìr has neither methodology nor universal principles ( $\left.q a w \bar{a}^{\prime} i d\right)$, except in a few cases; therefore, it cannot be defined as 'ilm, unlike other Islamic sciences that are bound to syllogistic logic, such as Islamic theoretical jurisprudence (Ușūl al-Figh) (Ibid., p. 5). The term "principle" here refers to a systematic method that always produces the same outcomes. For example, one of the exegetical principles discussed by

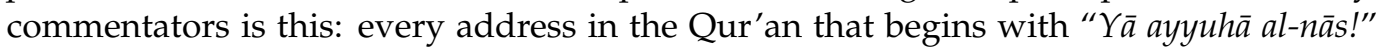
(O people!) is directed to Meccans, with "Yā ayyuhā alladhīna āmanū!" (O believers!) to Medinans, and with "Yā ahl al-Kitāb!" (O people of the Book!) to Jews and Christians (Ibid., p. 79). However, according to al-Fanārī, Tafsìr has only a few principles like this, and the scarcity of such principles prohibits it from being classified as 'ilm. Therefore, he preferred to describe Tafsīr as "knowledge" (or "study") (ma'rifa) rather than 'ilm (Ibid., pp. 5, 15). Al-Fanārī's pupil, Muhyī al-Dīn al-Kāfiyajī (d. 1474), emphatically defended the claim that Tafsī has principles ( $q a w \bar{a}^{\prime} i d$ ) in a treatise he wrote in the field of 'ulüm al-Qur' $\bar{a} n$, which won recognition as one of the early examples of its genre, to elucidate these exegetical principles (Al-Kāfiyajī 1998). However, it is hard to say that al-Kāfiyajī successfully defended the idea because his very brief work identified only a few principles regarding the topics of muhkam/mutashäbih (obvious/unclear verses) and naskh (abrogation in the Qur'an) (Ibid., pp. $51-72) .{ }^{30}$

A second issue regarding whether Tafsìr should be considered 'ilm involved scholarly debate over whether it is about the comprehension of universals (kulliyāt) and is pertinent to assent (tașdī $q$ ) or is about the comprehension of particulars (juz'iyyāt) and concerns conceptualization (tașawwur). The former approach treats Tafsīr as 'ilm, having principles by which it is able to produce decisive knowledge, and the latter as ma'rifa, which can be conceived of as indecisive knowledge. ${ }^{31}$ For example, al-Sayyid al-Sharīf al-Jurjānī (d. 1414), a prolific author and encyclopedic scholar who established himself in Central Asia in the Timurid period, viewed Tafsìr as an 'ilm that produces assent, because it provides 
meanings to the words of the text, and, therefore, it has the authority to make a judgement (yatadamman hukm) on the text (Al-Zurqānī 1943, vol. 1, p. 471). On the other hand, 'Abd al-Hakīm al-Siyalkūtī (d. 1656), a well-known Mughal scholar, argued that Tafsīr is about concepts, because it has no function other than linguistic description (al-ta'árif al-lafziyya) (Ibid.). According to al-Fanārī, who classified Tafsīr as ma'rifa, most of its outcomes are inconclusive (zannī), since most of the Qur'anic comments are conjectural, due to the fact that they are based on either reason or singular hadiths $(\bar{a} h \bar{a} \bar{d})$, both of which, according to the Hanafī School, provide only conjectural knowledge. In addition, we have already seen that al-Fanārī denied that Tafsìr has principles, which, in his opinion, makes its outcomes inconclusive. The primary motive that led al-Fanārī to this conclusion was, of course, his desire to be able to justify Sufi exegesis by validating comments based on frameworks other than tradition, such as intellect or mystical knowledge. He meant to say that all these types of interpretation, including exegesis based on narrations, produce inconclusive conjectural knowledge; therefore, they are at the same level in terms of authority. Although al-Fanārī's main concern here was to justify Akbarī Sufi hermeneutics, he came to a very important conclusion concerning the authority of Tafsìr to determine God's intention in the words of the Qur'an. If all Qur'an commentaries based on conjectural knowledge are regarded as inconclusive, no commentary among them may be exclusively accepted as God's intention.

By characterizing Tafsīr as ma' rifa rather than as 'ilm, al-Fanārī accepted the idea that multiple interpretations of the same text are valid. At the center of the discussion here lies the question "can we know God's intention with certainty?"32 Al-Fanārī answered this question by embracing a partial relativism. He stated, "multiplicity [of the divine intention] is not in a generic truth (al-haqiqga al-naw'iyya); rather, in its different particulars (al-juz'iyyāt al-mukhtalifa) due to diversity of perceptors (qawābil)" (Al-Fanārī [1325] 1907, p. 5). By "generic truths," he means the foundational principles of Islam, such as oneness of God, which do not change according to different perceptions. These universal truths are established by self-evidence or mutawātir reports (but not by $\bar{a} h \bar{a} \bar{d}$ hadiths). Aside from these universal principles, particulars might be interpreted in a variety of ways. As a result, al-Fanārī differentiated between God's "known" and "assumed" intentions in his definition of Tafsìr: "Tafsìr is the knowledge of the states of God's speech in terms of its Qur'anness and in terms of its indication to God's intention that is known or assumed according to the human capacity" (Al-Fanārī [1325] 1907, p. 5) ${ }^{33}$. While God's "known" intention refers to "generic truths," all other comments can be categorized as God's "assumed" intention, and they stand at the same level of authority. The most crucial point in the statement is that al-Fanārī accepted that God's intention in the text differs according to the "diversity of perceptors". This means that commentators play a major role in determining God's intention.

In reality, al-Fanārī, who certified every comment made on the Qur'an as God's intention, was following in the footsteps of his predecessors in the Akbarī School. It is well known that Ibn al-'Arabī, who grounded his esoteric Qur'anic comments in literalism by intensely adhering to etymology, generated unconventional interpretations based on the cognates of words. According to him, if the cognate of a word supports an interpretation, that interpretation must be acknowledged as valid. In an attempt to justify this method, he states,

Every sense (wajh) which is supported (ihtimāl) by any verse in God's Speech (kalām)-whether it is the Koran, the Torah, the Psalms, the Gospel, or the Scripturein the view of anyone who knows that language (lis $\bar{a} n)$ is intended (maqșu$d)$ by God in the case of that interpreter (mutaawwil). For His knowledge encompasses all senses .... Hence, every interpreter correctly grasps the intention of God in that word (kalima). This is the truth, "[a Mighty Book:] to which falsehood comes not from before it nor from behind it; a sending down from One Wise, Praiseworthy" (41:42) upon the heart of him whom He chooses from among His servants. Hence no man of knowledge can declare wrong an interpretation, which is supported by the words (lafz). He who does so is extremely deficient in 
knowledge. However, it is not necessary to uphold the interpretation nor to put it into practice, except in the case of the interpreter himself and those who follow his authority. ${ }^{34}$ (Ibn al-'Arabī 2010, vol. 5, p. 22)

Two points stand out here. First, according to Ibn al-'Arabī, every etymologically possible interpretation is a meaning intended by God, which no one can refute. Second, this interpretation cannot be taken as the only truth nor be binding for everybody. It is binding only on those who choose to accept the interpreter's authority. In line with Ibn al-'Arabī's ideas, al-Qūnawī stated,

Among the words of the Qur'an, there is no word that has many meanings in the language but all its meanings are meant by God. If a commentator comments on God's speech [i.e., the Qur'an] according to the requirement of its language and in a way that does not violate the indubitable religious principles (al-ușūl al-shar'iyya al-muhaqqaqa), this [comment] is true and God's intention. [The accuracy of the comment] is with respect to the commentator and those who share his state, taste, and understanding. (Al-Qūnawī1969, p. 334)

Al-Fanārī paraphrased this statement by al-Qūnawī as follows: "all interpretations of the Qur'anic text based on either sound narration (riwāya sahīha) or sound rational deduction (dirāya șah̄iha) are God's intention. But this is according to the levels (marātib) and receivers (qawābil), not [binding] for everyone" (Al-Fanārī [1325] 1907, p. 5). We see by this statement that if an interpretation is based on șahih report or sound cognizance, it should be considered legitimate and true, according to al-Fanārī. However, this interpretation cannot claim to bind anyone other than the interpreter. The "assumed" intention al-Fanārī adds to the definition of Tafsi $\bar{r}$ implies that all the comments that meet the conditions are equally valid, even the opposing ones. These comments have varying degrees of preferability, however, depending on the various scholarly and spiritual capacities of the commentators. As a result, al-Fanārī adds to his definition of Tafsīr the phrase "human potential" (al-tāqat alinsāniyya) in relation to the ability to know God's intention. This phrase suggests gradations among exegetes and in the preferability of their exegesis. The comments of those with more scholarly and spiritual capacity are more acceptable because they come closer to grasping God's intention. Therefore, a commentator not only "assumes" God's intention, but also identifies its degree of preferability among other "assumed" intentions.

\section{Concluding Remarks}

One of the most intense debates among modern Muslim intellectuals concerns the changeability of Shari'a rules in keeping with changing times. Many modern scholars, some of whom are mentioned in this study, support this idea through contextual readings of the Qur'an, which highlight the principles of the scriptural text, rather than how the text was understood in a certain context. Even though it sounds reasonable to think that rules and laws ought to change over time, this idea has been rejected by many because the Shari'a rules expressed in the Qur'an are considered verbatim expressions of the eternal divine will, and admission of their changeability is seen to jeopardize a person's faith. However, as I argue in this paper, it is possible to find in classical Islam the theological and theoretical background for contextual reading of the scripture and, consequently, the changeability of the laws found in the scripture over time.

Mu'tazilite thinkers, Muslim philosophers (not mentioned in this study), philosophical Sufis (and other Sufis influenced by them), and the Sunni theological schools other than the Hanbalīs, distinguished between limitless divine speech and its limited manifestation in the human context, although they expressed this belief differently. According to the Ash'arīs and Māturīdīs, the speech of God and its expression in human language in the form of sacred scriptures are not the same thing. The former is an eternal, transcendent, and immutable divine attribute; the latter is "created" by God or "transformed" into something we understand in the angel or the prophet. These theologians did not approve of the idea that God speaks using created elements such as letters and sounds. In claiming that divine speech is different from its form in human language, these Islamic schools actually 
acknowledged the contextuality of the scriptures, that is, the idea that they appear in a historical context. As a result, the unlimited, eternal and universal divine will becomes embroiled in contextual issues at the moment of its transfer to human language. In other words, the people we call prophets, who are believed to have been given the ability to communicate with God, receive messages concerning the specific environment in which they are situated during their communication with the Divine. Consequently, the divine will, which finds its expression in the scriptures, emerges within the boundaries of human language and comprehension and points, as a matter of fact, to specific issues. For example, it answers a question, it mentions an event, it addresses the situations of certain individuals, it reflects the characteristics of the time and place in which it appears, and so forth. The

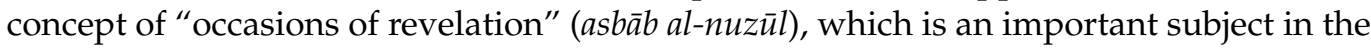
Islamic discipline of Qur'anic interpretation, refers to the fact that the revelation of the Qur'an appeared at a certain time and place and has an undeniable connection with them.

Another aspect of the discussion concerns the authority of Tafsis to explicate divine intention in the text of the Qur'an. As we have seen, some scholars do not recognize Tafsīr as one of the Islamic 'ulūm, rendering most of its outcomes-i.e., Qur'anic comments based on reason or $\bar{a} h \bar{a} d$ hadith reports-conjectural. Following Ibn al-'Arabī and al-Qūnawī, al-Fanārī thought that commentators merely "assume" God's intention in the text and held that no one can falsify another's comments, since, at the end of the day, all comments are assumptions and exist at the same level of authority. Some comments, however, may be favored by the Muslim community over others. This is a crucial conclusion because it brings public opinion to the forefront in discerning the divine intention in the text. It also implies that divine intention can be perceived differently in different contexts, or in other words, divine intention is neither static nor unilateral but takes shape in keeping with a certain context and is subject to change in another. This view, which finds its most sophisticated expression in al-Fanārī, supports what the modern contextualist approach seeks to achieve, by strongly emphasizing the role of context in understanding the divine message, as opposed to the traditionalist view, which, as we saw in al-Wāhidī's statement, embalms one understanding as the only meaning of the Qur'an and ostracizes alternative meanings.

Funding: This research received no external funding.

Institutional Review Board Statement: Not applicable.

Informed Consent Statement: Not applicable.

Data Availability Statement: Not applicable.

Conflicts of Interest: The author declares no conflict of interest.

\section{Notes}

1 When al-Sulamī's Sufi commentary appeared, many scholars met this commentary with resentment while many others exuberantly celebrated it. Muhammad ibn Aḥmad al-Dhahabī (d. 1348), an eminent medieval historian and traditionist, records how scholars and rulers welcomed al-Sulamī's work with great admiration. He also records negative opinions about the work. Al-Dhahabi's following statement very well summarizes people's mixed feelings about the commentary: "Some leading scholars (a'imma) considered this (work) heresy (zandaqa) of the Bātiniyya, while some others considered it wisdom ('irfān) and truth (haqīqa)" (Al-Dhahabī 1982-1983, vol. 17, p. 252).

2 For al-Wāhidī's life and works and a discussion of the hermeneutical approaches adopted by him throughout his career, see (Saleh 2006, pp. 223-43).

3 In his Interpreting the Qur'an, Abdullah Saeed identifies three approaches regarding the interpretation of ethico-legal verses of the Qur'an - textualist, semi-textualist, and contextualist—and he explains at length the contextualist approach (Saeed 2006).

These concepts can be read together in Abdullah Saeed's Interpreting the Qur'an, in terms of their relationship with contextualism. Reformist scholars, who are concerned with the regression of the Muslim world and try to find solutions for the problems of the Muslim community, have produced similar ideas, among which the following stand out: (a) the gate of $i j t i h \bar{a} d$ (process of making a legal decision by reason) is not closed, and Muslim scholars should produce ijtihāds as much as they can; (b) the changeability of Islamic rules with changes of context should be taken into consideration; (c) new methods of interpreting the sacred texts should be developed; (d) there are questions regarding the authenticity and authority of the hadith (prophetic tradition); and (e) 
it is not necessary to adhere to only one legal school (madhhab) for every legal matter; it is possible to accept the judgments of other schools under certain circumstances (the principle of talfiq).

For al-Tahtāwī's life, works and thoughts, see (Heyworth-Dunne 1939; Hourani 1983, pp. 69-83; Newman 2020).

For Khayr al-Dīn Pasha's thoughts, see (Hourani 1983, pp. 84-94).

For al-Afghān̄'s extensive biography, see (Keddie 1972).

For the life of Mehmed Seyyid Bey, see (Kara 1997).

Abu Zayd's Qur'anic hermeneutics can be seen in details in his Naqd Khițāb, Mafhūm al-Naș̣, and Textuality. For a brief summary of his hermeneutical ideas, see (Abu Zayd 2006, pp. 93-99).

For a summary of the opinions of the Islamic theological schools on divine speech, see (Gardet n.d.; Heemskerk n.d.). For a detailed analysis of the theological debates on divine speech and the Qur'an, see (Wolfson 1976, pp. 235-303).

Al-Ash'arī reports many opinions attributed to the $\mathrm{Mu}^{\prime}$ tazilite theologians. According to these reports, all the theologians of this school agree on the createdness of divine speech but disagree on the details (Al-Ash'arī 1963, pp. 191-94).

This teaching became the official policy during the reign of the Abbasid caliph al-Ma'mūn (r. 813-833) and was applied by his two successors. During this period, called the Mihna (inquisition, trial or persecution), scholars were tested and forced to accept the doctrine of the "created Qur'an" (Hinds n.d.).

For an extensive survey and detailed analysis of 'Abd al-Jabbār's speculative theology, see (Peters 1976).

Ahmad ibn Hanbal is portrayed in the Sunni sources as one of the scholars who resisted the official order to accept the doctrine of the creation of the Qur'an during the Mihna period. He was imprisoned due to his refusal (Laoust n.d.).

According to Madelung, the traditional standpoint turned, in time, into adoption of the doctrine of "eternal speech" and the "uncreated Qur'an." He states, "The traditional denial that the Koran was created, rather than spoken, by God thus was turned into a positive thesis, that of the eternity of the Koran." In addition, the traditionalist position regarding the eternity of the Qur'an during the pro-Mihna period is ambiguous. Opinions both affirming and denying the eternity of the Qur'an are reported in the sources (Madelung 1985).

Wolfson calls this view the "inlibration" of pre-existent divine speech, drawing an analogy to the Christian controversy over the beliefs of Christ's incarnation and His two natures, human and divine (Wolfson 1976, p. 246).

For example, al-Taftāzānī (d. 1390), a renowned polymath who lived during the Timurid period, stated in his commentary on al-'Aqā'id al-Nasafiyya, " ... It can be said that 'the Qur'an, speech of God, is uncreated.' Otherwise, it should not be said that 'the Qur'an [the book] is uncreated' in order not to call to mind that [the book] formed by sound and words is eternal, just as the Hanbalīs assert because of their ignorance or stubbornness"' (Al-Taftāzānī 1974, p. 56).

'Abdullāh ibn Kullāb (d. 854), who is considered a forerunner of al-Ash'arī, described God's speech as His divine attribute, which inheres in Him, unitary, simple, and indivisible. Subsequent Sunni theologians agreed with him on this description of the speech as a divine attribute. For an analysis of the statements attributed to Ibn Kullāb, see (Wolfson 1976, pp. 248-51).

Ibn Kullāb taught that the text of the Qur'an is not uncreated like its heavenly prototype, "rather it is only an expression ('ibāra) of God's speech, its created phonetical form." (Ess 1996, p. 182). Like Ibn Kullāb, prominent Māturīdī and Ash'arī scholars such as Abū al-Yusr al-Bazdawī (d. 1100), Abū Muțī’ Makhūl al-Nasafī (d. 930), and Abū Hāmid al-Ghazzālī (d. 1111) did not affirm the uncreatedness of expression (lafz) (Ibid., p. 185). Wolfson shows that al-Ash'arī's opinion regarding the eternity of the expressions of the Qur'an is ambiguous. According to his statements in al-Ibāna, al-Ash'arī appears to have thought like Ibn Hanbal on this issue. However, according to the statements attributed to him by al-Shahrastānī, al-Ash'arī sounds just like Ibn Kullāb (Wolfson 1976, pp. 254-57).

See Q. 56:77-78, Q. 43:3-4, and Q. 85:21-22 (Ali 1983).

Qādī 'Abd al-Jabbār uses the consensus among Muslims regarding the existence of the heavenly form of the Qur'an in the Lawh to justify the Mu'tazilī doctrine of the creation of the Qur'an (Al-Asadābādī 1965, pp. 324-25; see also Peters 1976, p. 394).

Al-Zamakhsharī states, "[God speaks] by creating the speech that sounds in some physical objects or He creates it as a writing in the Lawh" (Al-Zamakhsharī 1998, vol. 2, p. 501).

Al-Rāzī mentions three possibilities when he explains how the Angel seizes the eternal speech of God: (1) God creates the abilities of "hearing" (sam') and "verbalizing" ('ibāra) in the Angel; (2) God creates writing that reflects His speech in the Lawh, so that the Angel reads and memorizes it; or (3) God creates a sound that manifests as speech in certain physical objects, so that the Angel grasps it (Al-Rāzī 2000, vol. 2, p. 30). In addition, see (Al-Rāzī [1328] 1910, p. 130). Goldziher, who argues that the Mu'tazila influenced al-Rāzī in certain respects, presents this as evidence for his argument (Goldziher 1912, p. 213).

For a semantic analysis of the terms inzāl, nuzūl and tanzìl, see (Wild 1996, pp. 137-53).

Both opinions were attributed to Ibn Kullāb and adopted by his followers from the Ash'ariyya and the Māturīdiyya (Wolfson 1976, p. 290).

The idea of "creation of the Qur'anic expressions through recital" is also attributed to Ibn Kullāb (Wolfson 1976, pp. 249-50). 
This hadith is not found in the nine major hadith collections (al-kutub al-tis'ah), but it was widely dispersed in later sources of hadith and tafsīr. For a version of the hadith, see (Al-Tabarī 2003, vol. 1, p. 22). For a comprehensive study of the hadith and its interpretations by Sufi and non-Sufi scholars over the course of time, see (Calis 2020, pp. 1-34). The phrase "without any chronological order" implies that these parts have not been actualized.

Jalāl al-Dīn al-Suyūṭī, al-Kāfiyajī's pupil, does not seem satisfied with his teacher's work (Al-Suyūṭī 1974, vol. 1, pp. 16-17). For the differences between 'ilm and ma'rifa, see (Bearman et al. n.d.; Arnaldez n.d.).

This is actually an important debate in Islamic jurisprudence. Al-Fanārī is aware of this jurisprudential debate. See (AlFanārī [1325] 1907, p. 5).

For an analysis of the definition, see (Calis 2018, pp. 165-73).

The translation is Chittick's (1989, p. 244). For the similar passages, see (Ibn al-'Arabī 2010, vol. 6, p. 631 and vol. 10, p. 207).

\section{References}

Abu Zayd, Nasr. 1999. Dawā'ir al-Khawf: Qirā'a fī khițāb al-mar'a. Beirut: Al-Markaz al-Thaqāfī al-'Arabī.

Abu Zayd, Nasr. 2006. Reformation of Islamic Thought: A Critical Historical Analysis. Amsterdam: Amsterdam University Press. Al-Asadābādī, 'Abd al-Jabbār ibn Aḥmad. 1965. Al-Muhịt bi-l-taklīf. Al-Qāhira: Al-Dār al-Miṣriyya li-l-ta'līf wa-l-tarjama.

Al-Ash'arī, Abū al-Hasan Alī ibn Ismā̄îl. 1963. Kitāb Maqālāt al-Islāmiyyīn wa-ikhtilāf al-muṣallīn. Vīsbādin: Dār al-Nashr Frānz Shtāynir. Al-Bazdawīi, Abū al-Yusr Muhḥammad ibn Muhạmmad. 2003. Uṣūl al-Dīn. Al-Qāhira: Al-Maktabat al-Azhariyya li-l-turāth.

Al-Dhahabī, Muhammad ibn Aḥmad. 1982-1983. Siyar a'lām al-nubalā'. Bayrūt: Mu'assasat al-Risāla.

Al-Fanārī, Shams al-Dīn Muhammad ibn Hamza. 1907. 'Ayn al-a'yān: Tafsīr al-Fātiha. İstanbul: Rifat Bey Matbaası. First published 1325. Ali, Abdullah Yusuf. 1983. The Holy Quran: Text, Translation and Commentary. Brentwood: Amana.

Al-Kāfiyajī, Muhȳ̄ al-Dīn Muhammad ibn Sulaymān. 1998. Al-Taysīr fĩ qawā̄id 'ilm al-Tafsīr. Edited by Muștafā Muhammad Husayn al-Dhahabī. Al-Qāhira: Maktabat al-Qudsī.

Al-Qūnawī, Sadr al-Dīn Muhammad ibn Ishāq. 1969. I'jāz al-bayān fĩ ta'wīl Umm al-Qur'ān. Edited by 'Abd al-Qādir Ahmad 'Atāā. Al-Qāhira: Dār al-Kutub al-hadītha.

Al-Rāzī, Fakhr al-Dīn Muhammad ibn 'Umar. 1910. Asās al-taqdīs. Miṣr: Maṭba'at Kurdistān al-'ilmiyya. First published 1328.

Al-Rāzī, Fakhr al-Dīn Muhammad ibn ‘Umar. 2000. Mafātīh al-ghayb. Bayrūt: Dār al-Kutub al-'ilmiyya.

Al-Suyūṭī, Jalāl al-Dīn 'Abd al-Raḥmān. 1974. Al-Itqān fì 'uìum al-Qur'ān. Al-Qāhira: Al-Hay'at al-Mișriyya al-'āmma li-l-kutub.

Al-Tabarān̄̄, Abū al-Qāsim Sulaymān b. Ahmmad. 1994. Al-Mu’jam al-kabīr. Al-Qāhira: Maktabat Ibn Taymiyya.

Al-Ṭabarī, Abū Ja'far Muhammad b. Jarīr. 2003. Tafsīr al-Tabarī: Jāmi' al-bayān 'an ta' wīl ây al-Qur'ān. Riyadh: Dār 'Ālam al-Kutub.

Al-Taftāzānī, Mas'ūd ibn 'Umar. 1974. Sharh al-'Aqā'id al-Nasafiyya fì uṣūl al-dīn wa-'ilm al-Kalām. Dimashq: Wizārat al-Thaqāfa wa-l-Irshād al-Qawmī.

Al-Zamakhsharī, Maḥmūd ibn 'Umar. 1998. Al-Kashshāf'an haqā'iq ghawāmiḍ al-tanzīl wa-'uyūn al-aqāwīl fī wujūh al-ta'wīl. Al-Riyāḍ: Maktabat al-`Ubaykān.

Al-Zarkashī, Badr al-Dīn Muḥammad ibn 'Abdullāh. 1957-1958. Al-Burhān fì 'ulūm al-Qur'ān. Al-Qāhira: Dār Ihyā̄' al-kutub al-'Arabiyya.

Al-Zurqānī, Muhammad 'Abd al-'Aẓ̄m. 1943. Manāhil al-'irfān fī 'ulūm al-Qur'ān. Al-Qāhira: Dār Ihyā' al-kutub al-'Arabiyya: 'Īsā al-Bābī al-Halabī.

Arnaldez, Roger. n.d. Ma'rifa. In Encyclopaedia of Islam, 2nd ed. Brill Online. Available online: http:/ / referenceworks.brillonline.com/ browse/encyclopaedia-of-islam-2 (accessed on 21 March 2018).

Bearman, Bianquis T., E. J. van Donzel, C. E. Bosworth, and W. Heinrichs. n.d. 'Ilm. In Encyclopaedia of Islam, 2nd ed. Brill Online. Available online: http:/ / referenceworks.brillonline.com/browse/encyclopaedia-of-islam-2 (accessed on 21 March 2018).

Calis, Halim. 2018. Akbarī Hermeneutics in Shams al-Dīn al-Fanārī's Qur'an Commentary on the Chapter al-Fātiḥa. Ph.D. dissertation, University of Chicago, Chicago, IL, USA.

Calis, Halim. 2020. The 'Four Aspects of the Qur'an' hadīth and the Evolution of Sūfī Exegesis until Shams al-Dīn al-Fanārī (d. 834/1431). Journal of Qur'anic Studies 22: 1-34. [CrossRef]

Chittick, William C. 1982. The Five Divine Presences: From Al-Qūnawī to Al-Qayșarī. The Muslim World 72: 107-28. [CrossRef]

Chittick, William C. 1989. The Sufi Path of Knowledge: Ibn al-'Arabī's Metaphysics of Imagination. Albany: State University of New York Press.

Ess, Josef Van. 1996. Verbal Inspiration? In The Qur'an as Text. Edited by Stefan Wild. Leiden and New York: E.J. Brill, pp. 177-94.

Gardet, Louis. n.d. Kalam. In Encyclopaedia of Islam, 2nd ed. Brill Online. Available online: http://referenceworks.brillonline.com/ browse/encyclopaedia-of-islam-2 (accessed on 21 March 2018).

Gimaret, Daniel. n.d. Mu'tazila. In Encyclopaedia of Islam, 2nd ed. Brill Online. Available online: http://referenceworks.brillonline. com/browse/encyclopaedia-of-islam-2 (accessed on 21 March 2018).

Goldziher, Ignác. 1912. Aus Der Theologie Des Fachr Al-Din Al-Razi. Der Islam: Zeitschrift Für Geschichte Und Kultur Des Islamischen Orients 3: 213-47. [CrossRef]

Heemskerk, Margaretha T. n.d. Speech. In Encyclopaedia of the Qur'ān. Available online: http://referenceworks.brillonline.com/ browse/encyclopaedia-of-the-quran (accessed on 21 March 2018). 
Heyworth-Dunne, James. 1939. Rifa'a Badawi Rafi' at-Tahtawi: The Egyptian Revivalist. Journal of the British Society of Orientalist Studies 9: 961-67.

Hinds, Martin. n.d. Mihna. In Encyclopaedia of Islam, 2nd ed. Brill Online. Available online: http:/ / referenceworks.brillonline.com/ browse/encyclopaedia-of-islam-2 (accessed on 21 March 2018).

Hourani, Albert. 1983. Arabic Thought in the Liberal Age. Cambridge: Cambridge University Press.

Ibn al-'Arabī, Muhȳī al-Dīn. 2010. Al-Futūhāt al-Makkiyya. Al-Jumhūriyya Al-Yamaniyya: Wizārat al-Thaqāfa.

Ibn al-Ṣalāḥ, ‘Uthmān ibn 'Abd al-Raḥmān. 1980. Fatāwā Ibn al-Ṣalāh. Al-Qāhira: Maktabat Ibn Taymiyya.

Kara, Ismail. 1997. Turkiye'de Islamcilik Dusuncesi. Istanbul: Kitabevi Yayinlari.

Keddie, Nikki R. 1972. Sayyid Jamal al-Din "Al-Afghani". Los Angeles: University of California Press.

Laoust, Henri. n.d. Ahmad ibn Hanbal. In Encyclopaedia of Islam, 2nd ed. Brill Online. Available online: http://referenceworks. brillonline.com/browse/encyclopaedia-of-islam-2 (accessed on 21 March 2018).

Madelung, Wilferd. 1985. The Origins of the Controversy Concerning the Creation of the Qur'an. In Religious Schools and Sects in Medieval Islam. London: Variorum Reprints.

Newman, Daniel. 2020. Rifa'a al-Tahtawi: A 19th Century Egyptian Educationalist and Reformer. Edinburgh: Edinburgh University Press.

Peters, Johannes R. T. M. 1976. God's Created Speech: A Study in the Speculative Theology of the Mu'tazilî Qâdî l-Qudât Abû l-Hasan 'Abd al-Jabbâr bn Ahmad al-Hamadânî. Leiden: Brill.

Rahman, Fazlur. 1984. Islam and Modernity. Chicago: University of Chicago Press.

Rahman, Fazlur. 1979. Islam. Chicago: The University of Chicago Press.

Saeed, Abdullah. 2006. Interpreting the Qur'an: Towards a Contemporary Approach. London and New York: Routledge.

Saleh, Walid A. 2006. The Last of the Nishapuri School of Tafsīr: Al-Wāhịīī (d. 468/1076) and His Significance in the History of Qur'anic Exegesis. Journal of the American Oriental Society 126: 223-43.

Seyyid, Mehmed Emin. n.d. Madkhal: Ușūl-i Fiqh. Istanbul: Asitane Kitabevi.

Wild, Stefan. 1996. We Have Sent Down to Thee the Book with the Truth: Spatial and Temporal Implications of the Qur'anic Concepts of Nuzūl, Tanzīl, and Inzāl. In The Qur'an as Text. Edited by Stefan Wild. Leiden and New York: E.J. Brill, pp. 137-53.

Wolfson, Harry Austryn. 1976. The Philosophy of the Kalam. Cambridge: Harvard University Press. 